\title{
LESZÁLLÓ KÖZFORGALMÚ REPÜLŐGÉPEK ZAJÁNAK MÉRÉSE
}

\section{MEASURING OF LANDING AIRCRAFT NOISE}

\author{
Bera Bálint $^{1}$, Pokorádi László ${ }^{2}$ \\ ${ }^{I}$ Óbudai Egyetem Bánki Donát Gépész és Biztonságtechnikai Mérnöki Kar, \\ Magyarország1081 Budapest, Népszínház u.8.; balintbera@gmail.com \\ ${ }^{2}$ Óbudai Egyetem Bánki Donát Gépész és Biztonságtechnikai Mérnöki Kar, \\ Magyarország 1081 Budapest, Népszínház u. 8.; pokoradi.laszlo@bgk.uni-obuda.hu
}

\begin{abstract}
Nowadays, one of the most important environmental problems is noise and vibration. Their important part is the flying noise. To be able to manage, regulate and modeled, it is absolutely necessary knowing the deepest possible level accordingly. This knowledge acquired through measurements. This article presents a few examples of our measurements. The measurements were carried out in the near Budapest's Liszt Ferenc Airport.
\end{abstract}

Keywords: aviation, noise, measuring of noise.

\section{Összefoglalás}

A környezetvédelem problémáinak egyik legfontosabbika a zaj- és rezgésvédelem. Ezen a területen belül különíthető el a repülésből származó zaj. Ahhoz, hogy megfelelően tudjuk kezelni, szabályozni és modellezni, mindenképpen szükséges a lehető legmélyebb szintű ismerete. Ezt az ismeretet méréseken keresztül sajátíthatjuk el. A cikk a méréseink közül mutat néhány példát. A méréseket a budapesti Liszt Ferenc Repülőtér közelében végeztük el.

Kulcsszavak: légi közlekedés, zaj, zajmérés.

\section{Bevezetés}

A repülési zajnak a modernkori környezetvédelemben betöltött igen fontos szerepére több magyarázat is adódik. Elsősorban a légi közlekedés nagymértékü fejlődésében keresendő az egyik fő ok: a légitársaságok egyre több járatot közlekedtetnek, ráadásul a repülöterek számának növekedésével és forgalmuk bővülésével szélesebbé válnak a repülési zaj által érintett területek. Mivel pedig - gazdasági és kényelmi szempontok miatt - ma már a repülőterek többsége a lakott területekhez közel helyezkedik el (a városok gyakorlatilag a repülőterek felé terebélyesedtek), a fel- és leszállások során lesugárzott hangteljesítmény sokszor komoly problémát okoz a környék lakosságának. Márpedig a repülőgépek zajkibocsátása kis magasságon, a fel- és leszállási müveletek során a legnagyobb.

Fontos tehát, hogy létrehozzunk egy olyan szabályozási rendszert, ami alkalmas ennek a problémának a kezelésére. Ezt pedig úgy kell kivitelezni, hogy kompromisszum alakuljon ki a zaj által terhelt lakosság nyugalma, a légi közlekedés töretlen fejlődésének biztosítása és a repülés 
biztonság szavatolása között.

Sajnos a magyarországi szabályozási rendszer sok esetben hiányosnak, elavultnak bizonyul [1], ezért kiemelt feladatnak minősül frissítése.

Mindenképpen szükséges tehát megfelelő mérési eredmények birtokában lennünk, melyek segítségével megalapozhatunk egy szabályozási és modellezési rendszert.

Tanulmányunk célja a leszálló közforgalmú repülőgépek által keltett zaj mérésének bemutatása, valamint azok kiértékelése.

A cikk az alábbi fejezetekből áll: A 2. fejezetben ismertetjük a mérési körülményeket és az alkalmazott müszereket. A 3. fejezetben a mérési eredményeket és azok értékelését írjuk le. Végül, a 4. fejezetben összegezzük a tanulmányt.

\section{Mérési körülmények és mérő- müszerek}

A 2015-ös év során több esetben kerítettünk sort repülési zaj mérésére Budapest Liszt Ferenc Nemzetközi Repülötér környezetében. A mérési helyszín kiválasztásánál a következő fő szempontokat vettük figyelembe: átlagos repülési magasság; átlagos repülési sebesség; távolság a legközelebbi közúttól és vasúttól; repülési zaj nélkül mérhető egyenértékü A-hangnyomásszint; távolság a lakott területektől; beépítettség jellege.

A választott mérési helyszínt az 1 . ábra mutatja be.

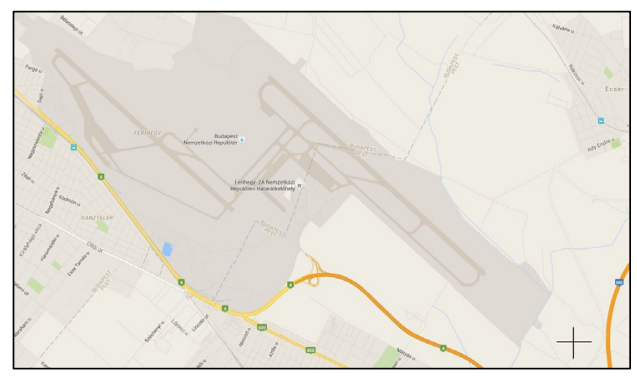

1. ábra. A zajmérések helyszine
A mérési időpontokat előzetes felmérést követöen, a járatsürüség és az időjárási körülmények alapján, választottuk ki. Ennek két oka volt: a repülötér forgalma a nyári és a téli hónapokban a legnagyobb, összel és tavasszal visszaesés tapasztalható. Ezen kívül a hét nem minden napján mutatkozik ugyan akkora járatürüség.

Méréseinket egy Svantek SVAN-945 első osztályú zajszintmérő műszerrel végeztük. Ez egy hitelesített, joghatással járó mérések elvégzésére is alkalmas müszer. A mérési eredmények helyességét kalibrálással biztosítottuk, amit minden mérési sorozat elött elvégeztünk.

A zaj-adatok mellett azonban szükségünk volt arra is, hogy megfelelő információkat szerezzünk az adott repülési műveletre jellemző adatokról. Elsősorban az adott mérésekkor fennálló repülési magasság és sebességadatok voltak fontosak a kiértékelés szempontjából. Mivel ezek felés leszállás során folyamatosan változnak, így egy időben kellett rögzítenünk ezeket a zajméréssel. A megoldást egy ADS-B (AutomaticDependentSurveillance-Broadcast - Automatikus légtérellenőrzés-adás) vevő jelentette volna, ami a repülögépek transzpondereinek jeleit képes érzékelni. Egy ilyen eszköz beszerzése nehézkes, ám helyette tökéletesen megfelelt egyDVB-T (Digital Video Broadcasting-Terrestrial digitális földfelszíni videó adás) vevő. Ez a megfelelő chipek megléte esetén képes a transzponderek 1090 MHz-es frekvenciáján dolgozni. Hordozható számítógépre csatlakoztatva biztosítottá vált, hogy egy időben rögzíthessük a repülési adatokat és a zajszinteket.

\section{Mérési eredmények és kiértéke- lésük}

A mérések egy része felszálló, más része leszálló manőver végrehajtása közben történt. Terjedelmi okokból jelen tanulmányban csak a leszállást végrehajtó köz- 
forgalmú repülőgépekre vonatkozó zajmérési eredményeket mutatjuk be és értékeljük ki.

A 2. ábrán Airbus A320-232 típusú repülögép leszállása során mért hangnyomásszint- és repülési magasság-értékek láthatók az idő függvényében.

A mérés kezdetén a repülőgép hozzávetőlegesen 600 méteres magasságban tartózkodott, majd fokozatosan süllyedt a fel-és leszállópálya szintjéig. Eközben a mért zajszintértékek egy jól behatárolható intervallumban átlépték a megengedett határértéket, esetenként súlyos mértékben, azaz 10 $[\mathrm{dB}]-\mathrm{t}$ is meghaladóan.

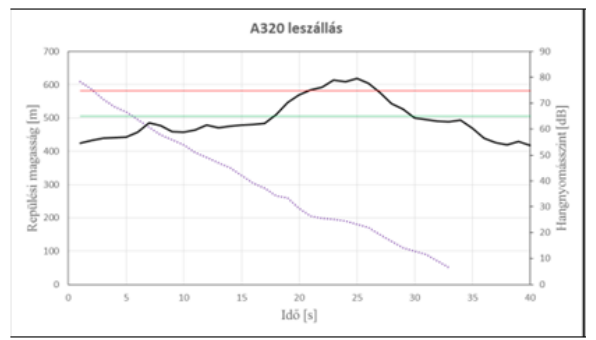

2. ábra. Airbus A320-232 típusú repülőgép leszállás közbeni hangnyomásszintjei a magasság vonatkozásában

Ezzel együtt az is látható, hogy a repülőgép áthaladása előtt és után egyaránt igen magas háttérzaj értékeket mértünk ebben a pontban. A repülésből származó zajterhelés tehát megemelte ugyan a zajszintet, mégpedig jóval a határérték fölé, azonban szélesebb időintervallumban szemlélve, a tartósan magas hangnyomásszintet egyéb forrásból származó zajok okozzák. Mivel pedig ebben az esetben a légi jármü relatíve kis távolságra volt a mérőmüszertől, zajkibocsátása a lehető legnagyobb mértékben járult hozzá a mérhető zajszint megemelkedéséhez.

Az Airbus A320 típuscsaládba tartozó, de az előbbitől némileg különböző, rövidebb törzsü A319-111 típusú repülögépnek ugyanebben a mérési pontban mért értékeit mutatja a 3. ábra.

Szembetünő különbség mutatkozik a zajszintértékek eloszlásában és azok maximumaiban egyaránt. Az A319-111-es pilótája a süllyedést kevésbé meredeken hajtotta végre. Ennek két következménye egyaránt megfigyelhetö a zajszintgörbén: a függvény nem mutat az 1 . ábrán láthatóhoz hasonló, kiugró értéket, viszont a határérték feletti, magasabb zajszint tartósabban megmarad.

Megjegyzendő továbbá, hogy az Airbus A319-111 típusváltozat kisebb méretéből fakadóan az úgynevezett aerodinamikai zaj is alacsonyabb, ez szintén befolyásoló hatással bír a mért hangnyomásszintre.

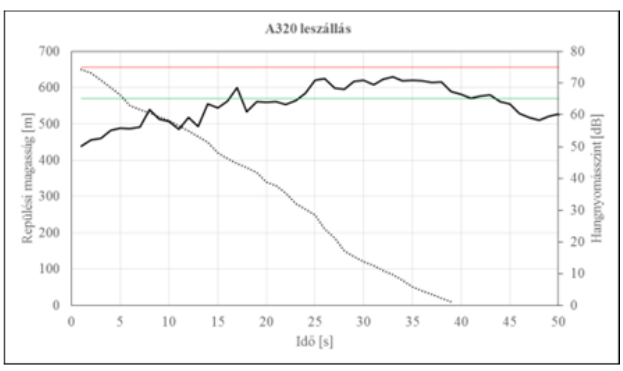

3. ábra. Airbus A319-111 típusú repülögép leszállás közbeni hangnyomásszintjei a magasság vonatkozásában

A repülési zajra jellemző karakterisztika mindkét esetben megfigyelhetö. A Dopplerjelenség, a manőverek jellege és a hajtómüvek elrendezése okozza, hogy a legnagyobb hangnyomásszintet nem akkor mérhettük, amikor a légi jármü közvetlenül a mérési pont fölött tartózkodott, hanem némileg később. Szintén megmutatkozik a földi visszaverődés jelensége is. Utóbbi hatását erösíti, hogy a repülőgépek ebben a vizsgált pontban relatíve közel voltak a mérömüszerhez, ami a többszörös visszaverődésnek köszönhetően némileg meg is emelte a mért hangnyomásszintet.

Ugyanebben a mérési pontban természetesen más típusú repülőgépek zajának mé- 
résére is sor került. Az adott napokra jellemző forgalom, illetve az egyes légitársaságok által üzemeltetett sokféle típusú légi jármű egyrészt lehetővé tette, hogy széles legyen a típuspaletta, másrészt meg is nehezítette, hogy egy adott típusra vagy típusváltozatra vonatkoztatva hajtsunk végre méréseket.

Budapest Liszt Ferenc Nemzetközi Repülötér forgalmának túlnyomó többségét két repülőgéptípus bonyolítja. Ezek a már említett Airbus A320, és a Boeing B737, illetve típusváltozataik. Kialakításukat tekintve hasonlóak: keskeny törzsü, két hajtómüves, alsószárnyas utasszállítók, jellemzően Európán belüli forgalomban alkalmazva. Ez utóbbi körülmény okán a legtöbb esetben nem a maximális hasznos teherrel dolgoznak.

Összehasonlításul az A320-ra vonatkozó eredményekkel, a 4. ábrán ugyan abban a mérési pontban mért, Boeing 737 típusú repülőgépre vonatkozó diagram látható.

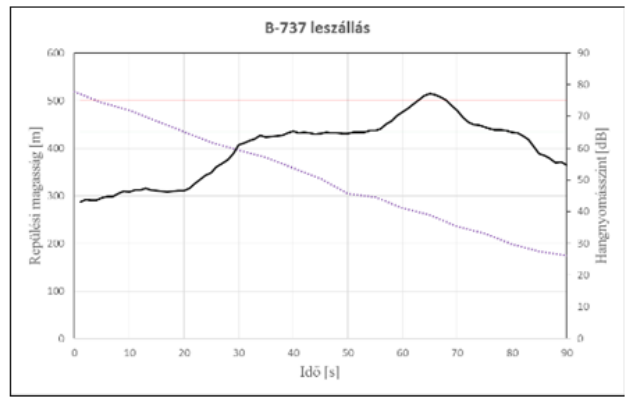

4. ábra. Boeing B737 típusú repülögép leszállás közbeni hangnyomásszintjei a magasság vonatkozásában

A hasonlóság szembeötlő, még a mért értékek tekintetében is. Egyedül a siklópályája meredeksége okozott változást, ami leginkább nem típus-specifikus. Mindkét esetben $80[\mathrm{~dB}]$ alatt maradtak a maximumok, s bár így is megtörtént a határérték súlyos átlépése, csak adott, rövid időintervallumban.

\section{4. Összegzés}

A vizsgált pontban a környezeti alapállapotot a repülési zaj nem állandóan, hanem eseti jelleggel változtatja meg. Ebből következik, hogy a határértékek teljesülését vagy túllépését is ezt ismerve kell kezelnünk. Belátható, hogy az egyes zajesemények sem mindig fejtenek ki ugyanolyan hatást, ahogy számos tényező változtatásával lehet befolyásolni a mérhető hangnyomásszinteket.

Amikor tehát meg akarjuk becsülni, hogy egy adott pontban milyen hangnyomásszintet fog okozni egy repülögép, mint zajforrás, több változó paraméterrel is számolnunk kell. A megfelelő pontosságú becsléshez ezért olyan modellt kell alkalmaznunk, ami megfelelően kezeli ezeket a változó paramétereket. Megfelelő megoldást kínálhat a Monte Carlo-szimuláció, melyről már bebizonyosodott, hogy alkalmas repülési zaj modellezésére [3].

\section{Szakirodalmi hivatkozások}

[1] Bera, Bálint: Repülési zaj hatásának elemzése a zajforrás és a környezeti alapállapot jellemzöinek összevetésével, Tudományos Diákköri Dolgozat, Budapest, 2015.

(konzulens: Pokorádi László; Bera József).

[2] Bera, József; Pokorádi, László: Helikopterzaj elmélete és gyakorlata, Campus Kiadó, Debrecen:,2010. $192 \mathrm{p}$.

[3] Bera, József: Légi közlekedés környezetbiztonsági kapcsolatrendszerének modellezése a helikopterzaj tükrében, doktori $(\mathrm{PhD})$ értekezés, Óbudai egyetem, Budapest, 2015.

\section{Köszönetnyilvánítás}

Tanulmányunk az Óbudai Egyetem Bánki Donát Gépész és Biztonságtechnikai Mérnöki Kar Müszaki Biztonságtudományi Szakmühely $-\mu \beta \sigma$ - keretében készült el.

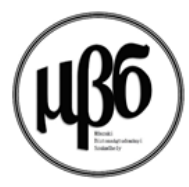

